\title{
Vannmannens barn
}

I 1906 utviklet August von Wassermann en test for å påvise syfilis. Da kunne man sette inn behandling før sykdommen var kommet langt, noe som var særlig viktig for barn som var smittet i mors liv. Ved Rikshospitalets barneavdeling hadde man prøvd mye - «kvikksølv som smørekur, salvarsan og andre arsenpreparater applisert dels intravenøst, dels intramuskulært, de forskjellige vismutprepatater intramuskulært». I Tidsskriftet nr. 24/1933 redegjøres det for en ny behandling som «av barnelæger overalt er møtt med en nesten enstemmig begeistring». Varig helbredelse var målet. Men det trengtes sterk lut, det nye midlet spirocid inneholdt også arsenikk (Tidsskr Nor Lægeforen 1933; 53: 1316-9).

\section{Spirocidbehandling av lues congenita}

(Diskusjonsinnlegg i Det norske medicinske selskaps møte 4. oktober 1933).

\section{Av Leif Salomonsen, Oslo.}

Det er en side ved den moderne antiluetiske behandling som ikke har fått den plass i herr Hvals foredrag som jeg mener den fortjener, nemlig spirocidbehandlingen av det kongenitt luetiske spebarn. Fra pediatrisk side kan dette synes forbausende, fordi denne behandling, ikke bare som innledende eller kombinert behandling, men som eneste behandling av det syfilitiske spebarn, av barnelæger overalt er møtt med en nesten enstemmig begeistring. Ikke bare gir den moderne spirocidbehandling en antiluetisk effekt som er vel så hurtig og vel så sikker som nogen annen antiluetisk behandling hos spebarnet. Den har dessuten den store fordel at medikamentet gis pr. os og man således helt undgår den hos spebarnet besværlige intravenøse applikasjon. (...)

Kuren varer i 94 dager. Der brukes i alt 160 tabletter spirocid à 0,25 g., altså til sammen $40 \mathrm{~g}$. spirocid. Det er en meget energisk kur med store doser som tilsikter varig helbredels e av sykdommen i og med denne kurs avslutning. På den annen side må man gjøre regning med at spirocid ikke er et indifferent stoff og at det i disse mengder kan gi anledning til forgiftninger. Blant de 12 barn som mitt materiale omfatter, er der riktignok bare en gang optrådt tegn på spirocidskade, nemlig en nerveskade i form av en slapp paraprese som gikk pent tilbake straks spirocid seponertes. Men under ingen omstendighet kan behandlingen overlates til foreldrene alene. Den må overvåkes av læge ved undersøkelse minst en gang for hver 10-dagers periode og doseringen individualiseres hvis forgiftningssymptomer optrer.

Materialet omfatter som nevnt 12 barn, 11 fra Rikshospitalets barneavdeling, 1 fra min privatpraksis. De var i alder $1-4$ måneder ved behandlingens begynnelse. Samtlige viste før behandlingen positiv W.R. Dessuten viste samtlige en betydelig forøket S.R. Hos alle fantes røntgenologisk luetiske benforandringer, vel det mest konstante kliniske symptom ved lues congenita. Hos 11 var milt og lever forstørret, som uttrykk for dem samtidige viscerale lues. Hos 8 fantes mere eller mindre utbredt luetiske eksantemer. Hos 7 langvarig snue. Hos 6 av 10 undersøkte viste øienbunnen en luetisk retinit, et mindre påaktet, men ikke desto mindre viktig symptom som i tvilstilfelle kan sikre luesdiagnosen.

Disse kliniske symptomer svant efterhvert under spirocidkurens fremadskriden. Samtidig viste disse som regel debile, dystrofiske
Tabell II. Wassermanns Reakjon.

\begin{tabular}{|c|c|c|c|c|c|c|}
\hline & \multirow{2}{*}{$\underset{\text { kuren. }}{\text { Før }}$} & \multirow{2}{*}{$\begin{array}{c}\text { Efter } \\
\text { kuren. }\end{array}$} & \multicolumn{4}{|c|}{ Efterunders $ø$ kt } \\
\hline & & & $1 / 2$ & 1 & $1^{1 / 2}$ & 2 år efter kuren \\
\hline G. G. & ++ & $\div$ & & $\div$ & & $\div$ \\
\hline T. K. & ++ & $\div$ & & & & \\
\hline H. E. & ++ & $\div$ & & & & $\div$ \\
\hline K. E. & ++ & $\div$ & & & & $\div$ \\
\hline A. $\mathrm{T}$. & ++ & $\div$ & $\div$ & (Død. & Seksjon: $n$ & male organer) \\
\hline B. H. & ++ & $\div$ & $\div$ & $\div$ & & \\
\hline S. D. & ++ & $+\div$ & & $\div$ & & \\
\hline B. J. & ++ & $\because$ & $\div$ & & & \\
\hline E. S. & ++ & $+\div$ & $\div$ & & & \\
\hline S. K. & ++ & $\div$ & $\div$ & & & . \\
\hline T. M. & ++ & $\div$ & & & & \\
\hline B. H. & ++ & - & & & & \\
\hline
\end{tabular}

barn en sterk vektøkning og en påfallende bedring av trivsel og almenbefinnende som ikke bare kan tilskrives spirocidets spesifikke virkning, men som til dels må skyldes en almindelig roborerende innflydelse av dette sterke arsenpreparat. Ved kurens avslutning var alle barn klinisk symptomfri og har heller ikke siden frembudt luetiske symptomer. Resultatet av W.R. fremgår av $t a$ b e 11 I I . Hos 10 barn var den blitt negativ og har siden i de tilfelle hvor den er blitt kontrollert videre, holdt sig negativ. Hos 2 barn var W.R. efter endt kur ikke straks blitt rent negativ, men var negativ ved efterundersøkelse $1 / 2$ og 1 år efter behandlingen.

Spørsmålet reiser sig om vi i og med denne ene kur virkelig har opnådd varig helbredelse av sykdommen eller om vi som hos voksne må være forberedt på å møte residiver, — om forholdene for så vidt ligger annerledes an hos spebarn så at man hos disse lettere kan opnå fullstendig tilintetgjørelse av spirochætene enn hos voksne. Materialet er for lite og observasjonstiden for kort til at dette spørsmålet nu kan besvares. Foreløpig stiller vi oss avventende. Så lenge barnene ved kontrollundersøkelse er klinisk symptomfri og W.R. holder sig negativ har vi tenkt oss at videre behandling kan utstå. 